\title{
集塵技術の多機能化グループ会活動報告
}

\section{Activity Report of Working Group on Advanced Dust Collection Technology}

\section{1.はじめに}

集塵技術の多機能化グループ会は, 平成 3 年から平成 17年まで活動した高温集塵グループ会の活動から, 新た に集塵関係の重要なテーマを抽出する形で発展させたグ ループ会である。前身である高温集塵グループ会では, 高効率発電技術など新技術において重要とされた, 集鹿 装置操作条件の過酷化（高温化や高圧化）における問題 点を検討してきた。その活動の中で, 今後の集塵技術に 要求される課題として出てきたのが, 集塵機能だけでな く, 他の環境污染質対策も踏まえた, 総合排煙処理シス テムとしての合理化や低コスト化を考えた上での多機能 化であった。平成18年度に発足した本グループ会では, さらなる環境対策技術の高度化・合理化を目指して, 集 塵技術の果たしうる役割，果たすべき役割の調查と，そ のために必要な技術を検討することを目的に活動してい る。

2. 発足と平成18年度の活動状況

（1）発足会兼第一回グループ会

発足が認められた平成18年の 7 月13日（木）に，発足 会を兼ねた第一回グループ会を, 東京・池袋のサンシャ インシティ文化会館にて，50名の出席者を集めて開催し た。この会議では、まずグループ会世話人代表の筆者よ り, 集塵技術の多機能化の意義, 現在考えられる多機能 化技術の検討対象，ならびに今後の活動方針を紹介し た。引き続き, 東京農工大学の神谷教授より, 前年の平 成17年10月に開催された，高温集塵グループ会の活動の 総決算的行事であった「第 6 回高温ガス精製国際会議」 の発表案件から, 集鹿技術の多機能化の視点で重要な内 容の紹介をして頂いた。その後, 電力中央研究所の白井 上席研究員より, 火力発電分野において実施または検討 中の集塵技術多機能化の代表例を紹介して頂き, 新東工 業の中根氏からは, バグフィルタを用いての多機能化技 術を紹介して頂いた。最後に, 総括討論として, 多機能 化技術に対する参加者の考え方，今後このグループ会に 期待する活動内容などを議論して頂き，盛況のうちに終 了した。また当日，総括討論の時間だけでは，完全に意 見を伺えない可能性もあったので，会員全員にアンケー 卜を実施し，今後の活動方針などに対して意見を頂い
た。これらの意見を踏まえ，平成18年度は，その後，二 回の会合を実施している。

(2) 第二回グループ会

第二回グループ会は, 粉体ナノテクノロジーグループ 会と合同で，9月5日(火)に，京都のキャンパスプラザ 京都にて開催した。集塵技術は，多機能化と同時に微粒 子の除去性能の向上が要求されている。特に近年, ナノ テクノロジーの重要性が高まるに応じて, 超微粒子を除 去するだけでなく，製品として回収する技術が注目され ている。第二回グループ会は, そのような視点から，ち ょうど国際会議があり来日したアメリカのDr. Powers, Dr. Poster おょび, タイのProf. Suyachittanont の三 氏を講師とし, ナノ粒子の採取, 分離ならびに分析・評 価などをテーマに開催した。すべて英語での講演で，通 訳も準備しなかったが, 41名の参加者を集め, 熱心な議 論が行われた。

（3）第三回グループ会

平成18年度最後のグループ会は, 平成18年12月14日 (木)に, 電源開発(株)の磯子発電所において, 設備見学 を中心に開催した。同発電所は, 横浜市内の狭い敷地に 設置されているため, 広い土地を必要とする湿式の排煙 脱硫装置が利用できず, 乾式の粒子充填層の脱硫装置を 設置しており，まさに集塵と脱硫の多機能装置として利 用している。またボイラ一自体も，タワーボイラーとい う狭い敷地で設置可能な方式を用いている。第三回は, 30名の参加者で発電所の概要や乾式脱硫装置の紹介, な らびに設備見学を行った。

\section{3. 今後の展望}

集塵技術の多機能化という。これまでとは異なる視点 でグループ会を開始したが, 関係者の積極的な支援もあ り，順調に情報交換, 情報収集などのグループ会活動が 始められたと思う。今後は, 発足会の討論やアンケート で出された活動に対する要望を踏まえ, 講演会, 見学会 などをバランスよく企画し，充実したグループ会にして 行きたいと思っている。関係諸兄の益々のご協力をお願 いしたい。

（電力中央研究所 牧野尚夫） 